Плодоводство и виноградарство Юга России № 51(03), 2018 г.

УДК 634.527: 634.84: 634.8.091-93

UDC 634.527: 634.84: 634.8.091-93

DOI: 10.30679 / 2219-5335-2018-3-51-78-87

DOI: 10.30679 / 2219-5335-2018-3-51-78-87

ФЕНОТИПИЧЕСКАЯ

И ГЕНЕТИЧЕСКАЯ

ХАРАКТЕРИСТИКИ НОВОГО

ТЕХНИЧЕСКОГО СОРТА

ВИНОГРАДА ФИОЛЕТТА ДАГЕСТАНСКОЙ СЕЛЕКЦИИ

Казахмедов Рамидин Эфендиевич д-р биол. наук

зав. лабораторией биотехнологии физиологии и продуктов

переработки винограда

Мамедова Сеидханым Мирмагомедовна мЛ. научный сотрудник

лаборатории селекции, сортоизучения

и интродукции винограда

Дагестанская селекиионная опытная станџия виноградарства и овощеводства - филиал Федерального государственного бюджетного научного учреждения «Северо-Кавказский федеральный научный иентр садоводства, виноградарства, виноделия», Дербент, Республика Дагестан, Россия dsosvio@mail.ru

Ильницкая Елена Тарасовна канд. биол. наук

зав. лабораторией сортоизучения

и селекции винограда

Федеральное государственное

бюджетное научное учреждение

«Северо-Кавказский федеральный научный иентр садоводства, виноградарства, виноделия», Краснодар, Россия

kubansad@kubannet.ru

Цель настоящей работы - определить наследование генотипических признаков и фенотипических особенностей в потомстве аборигенных дагестанских сортов винограда Гимра и Асыл кара, на примере новой перспективной

\section{PHENOTYPIC AND GENETIC CHARACTERISTICS OF A NEW TECHNICAL GRAPE VARIETY OF FIOLETTA OF DAGHESTAN BREEDING}

\author{
Kazakhmedov Ramidin Efendievich \\ Dr. Sci. Biol. \\ Head of Laboratory of Biotechnology, \\ Physiology and Grape \\ Processing Products
}

Mamedova Seidhanym Mirmagomedovna Junior Research Associate of Laboratory of Breeding, Variety's study and Introduction of grapes

Daghestan Selection

Testing Station of Viticulture

and Horticulture - branch

of the Federal State Budgetary Scientific

Institution «North Caucasian Federal

Scientific Center of Horticulture,

Viticulture, Winemaking»,

Derbent, Daghestan Republic, Russia

dsosvio@mail.ru

Ilnitskaya Elena Tarasovna

Cand. Biol. Sci.

Head of Laboratory

of Cultivar's study and Breeding of grapes

\section{Federal State Budget}

Scientific Institution

«North-Caucasian Federal

Scientific Center of Horticulture,

Viticulture, Winemaking»,

Krasnodar, Russia

kubansad@kubannet.ru

The purpose of this work is to determine the inheritance of genotypic traits and phenotypic features in the posterity of indigenous Daghestan grape varieties of Gimra and Asyl Kara, using as the example a new search was 
гибридной формы Фиолетта. Исследования проводились на сортах винограда, представленных в Ампелографической коллекции Дагестанской селекционной опытной станции виноградарства и овощеводства: Гимра (Тавалинский ранний), Асыл кара (Кизлярский черный), новый сорт Фиолетта (Гимра Х Асыл кара). Культура винограда - корнесобственная, орошаемая. При выполнении исследований использовались методы: полевой изучение фенологических, морфобиологических особенностей и фаз развития сортов; статистический вариационный анализ с определением достоверности полученных результатов; лабораторный, где генотипирование сортов винограда проводилось следующими микросателлитными маркерами - VVS2, VVMD7, VVMD27, VVMD5, VrZAG62, VrZAG79. В качестве контроля при молекулярном анализе в работе использовали сорт КабернеСовиньон. В статье представлены фенотипические особенности и ДНКпаспорта аборигенных дагестанских сортов винограда Гимра и Асыл кара, а также новой гибридной формы, полученной на основе гибридизации данных сортов, под названием Фиолетта, селекции ДСОСВО. Показана генетическая общность происхождения изучавшихся аборигенных сортов и особенности наследования фенотипических и генетических признаков от родительских форм. В статье отмечено, что полученные ДНК-паспорта сортов могут эффективно применяться для определения чистосортности посадочного материала и насаждений винограда данных сортов, определения их генетической близости к тому или иному сорту, для уточнения родительских форм образца, а также в спорных вопросах авторства сорта.

Ключевые слова: ВИНОГРАД, ГЕНОТИП, ФЕНОТИП, ДНК-ПАСПОРТ, АБОРИГЕННЫЕ СОРТА carried out with grape varieties from the Ampelographic collection of the Daghestan Selection Testing Station of Viticulture and Horticulture: as Gimra (Tavalinsky Ranniy), Asyl Kara (Kizlyar Cherny) and a new variety of Fioletta (Gimra x Asyl Kara). The culture of the grapes is on own roots and with use of irrigation. In the process of research the next methods were used: field study of phenological, morphological and biological features and phases of varieties development; the statistical variational analysis with determination of the reliability of the results; the laboratory method in which the genotyping of grape varieties was carried out by the following SSR-marker: VVS2, VVMD7, VVMD27, VVMD5, VrZAG62, VrZAG79. As a control for molecular analysis the CabernetSauvignon was used in our work. The article presents the phenotypic features and DNA-passports of indigenous Daghestan varieties of Gimra and Asyl Kara and a new hybrid form obtained by hybridization of these varieties, named Fioletta, of the DSTSV\&H breeding. The genetic commonality of the origin of the indigenous grape varieties studied, and the features of inheritance of phenotypic and genetic traits from parental forms are shown. It is noted in the article that the obtained DNA- passports of varieties can be effectively used to determine the clean varieties of planting material and grapes plantations of these varieties, and to determine the genetic proximity to one or another variety in the parent pair, and for the clarification of the parental forms of the sample, and also for the disputed questions of the authorship of the variety.

Key words: GRAPES, GENOTYPE, PHENOTYPE, DNA-PASSPORT, INDIGENOUS VARIETIES 
Плодоводство и виноградарство Юга России № 51(03), 2018 г.

Введение. Актуальной проблемой в выборе селекционного приоритета является обеспечение достаточного количества сортов винограда для формирования товарных конвейеров по сорто-сезонным группам, учитывающих значительную почвенно-климатическую дифференциацию ареалов возделывания. Совершенствование сортимента, базирующееся на изучении новых сортов, выделении лучших по основным параметрам - высокой экологической пластичности, продуктивности и качеству является актуальной задачей. Следует отметить, что основным недостатком районированного сортимента винограда Дагестана являются значительное доминирование одних и тех же сортов по всем районам промышленного виноградарства (Ркацители, Агадаи, Молдова и др.), что обедняет ассортимент винодельческой промышленности. [1]

Одним из ключевых требований, предъявляемых к сорту, для формирования высокого продукционного потенциала агроценоза и экологизации процессов является биологический потенциал сорта [2]. Эффективное использование растительных генетических ресурсов, устойчивых к биотическим стрессорам сортов винограда, позволяет снизить химическую нагрузку на экологию ампелоценозов, улучшить качество пищевой продукции, повысить продуктивность насаждений, продлить срок их эксплуатации [3].

Виноградарство, как и другие отрасли сельского хозяйства, в настоящее время сталкивается с серьезными проблемами, которые должны решаться только на основе целенаправленных и скоординированных исследований. Во многих областях исследований, включая исследования виноградного растения, есть необходимость улучшения обнаруживаемости, доступности и возможности повторного использования экспериментальных данных. Учитывая неоднородный характер полученных данных, транснациональный характер научного сообщества и накопленный опыт в других странах, сформировалась открытая рабочая группа в рамках Международной 
Плодоводство и виноградарство Юга России № 51(03), 2018 г.

программы генома виноградной лозы (www.vitaceae.org), призванная построить скоординированную Федерацию информационных систем, содержащих виноградные данные, распространяемые по всему миру, обеспечивать интегрированный набор интерфейсов, поддерживая предварительное моделирование данных, богатую семантическую интеграцию и инструменты интеллектуального анализа данных. Для развития этой системы, связывающей генотипы и фенотипы в научных исследованиях, следует представить новые идеи в биологии винограда и привести к созданию новых сортов для решения проблем биотического и абиотического стресса, экологических изменений и потребительского спроса [4].

Для сортов, предназначенных на техническую переработку (сока и вина), наиболее важным является высокий выход сока в сочетании с необходимыми для получения того или иного продукта кондициями по сахаронакоплению и кислотности сока ягод. В указанном направлении и ведется в настоящее время работа на станции в области селекции винограда. Отметим также, что в реестр селекционных достижений внесены технические сорта винограда селекции ДСОСВиО - Слава Дербента, Гимра новая; клоны Гюляби урожайный, Хатми урожайный.

Цель настоящей работы - определить наследование генотипических признаков и фенотипических особенностей в потомстве аборигенных дагестанских сортов Гимра и Асыл кара на примере новой перспективной гибридной формы Фиолетта.

Объекты и методы исследований. Исследования проводились на сортах винограда, представленных в Ампелографической коллекции ДСОСВиО: Гимра (Тавалинский ранний), Асыл кара (Кизлярский черный), новый сорт Фиолетта (Гимра х Асыл кара). Культура винограда - корнесобственная, орошаемая. Использовались методы: полевой - изучение феноло- 
гических, морфо-биологических особенностей и фаз развития сортов; статистический - вариационный анализ с определением достоверности полученных результатов; лабораторный, где генотипирование сортов винограда проводилось микросателлитными маркерами, рекомендованным в качестве основных для генотипирования Vitis vinifera: VVS2, VVMD7, VVMD27, VVMD5, VrZAG62, VrZAG79 [5-9]. В качестве контроля (рефренсного сорта) при молекулярно-генетической оценке использовали ДНК КабернеСовиньон. ДНК сортов Гимра и Асыл Кара были использованы из коллекции ДНК сортов винограда, выделенных из образцов Анапской ампелографической коллекции и сохраняющихся в СКФНЦСВВ (г. Краснодар).

Фиолетта - новый технический сорт винограда селекции филиала ДСОСВиО ФГБНУ «СКФНЦСВВ» (гибридная форма Г-270), получен путем скрещивания сортов Гимра и Асыл кара, относится к группе сортов среднего срока созревания. Продолжительность вегетационного периода от распускания почек до полной зрелости 127-128 дней при сумме активных температур $2738^{\circ} \mathrm{C}$.

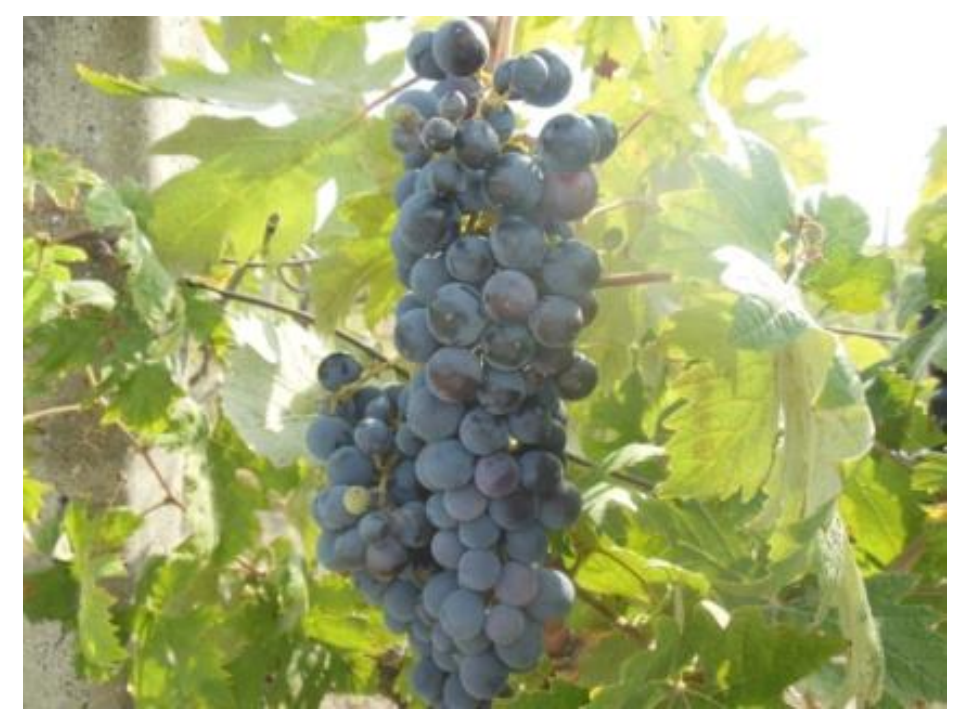

Рис. 1. Новый технический сорт винограда Фиолетта 
Обсуждение результатов. Анализ фенотипических признаков аборигенных сортов Гимра и Асыл кара и гибридной формы Фиолетта показал, что признаки листа потомства аборигенных сортов в большей степени унаследованы от материнской формы - сорта Гимра (рис. 2-4, табл. 1).

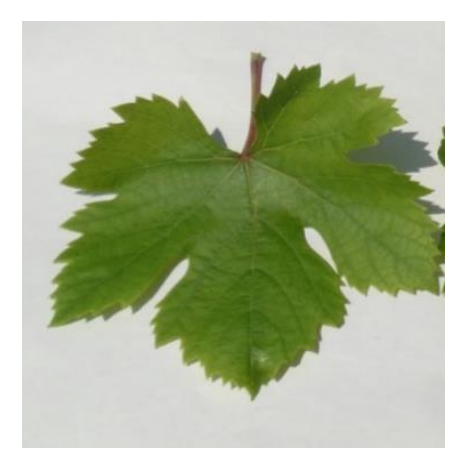

Рис. 2. Родительская форма, сорт Гимра

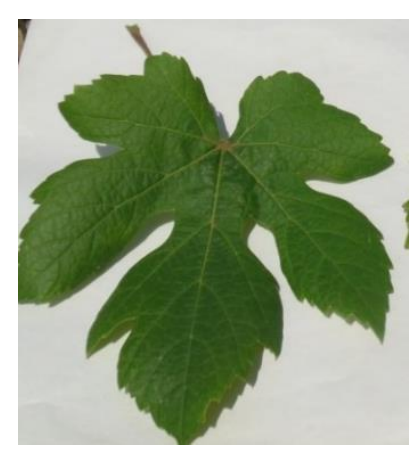

сорт Асыл кара

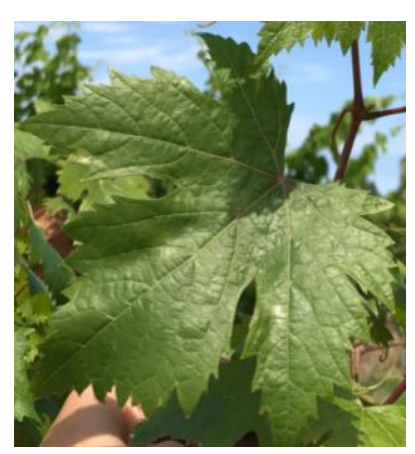

Рис. 4. Гибридная форма, сорт Фиолетта

Таблица 1 - Фенотипические особенности аборигенных сортов винограда

\begin{tabular}{|c|c|}
\hline Гимра (Тавалинский ранний) & Асыл кара (Кизлярский черный) \\
\hline $\begin{array}{l}\text { 1. Коронка молодого побега открытая, } \\
\text { зеленая, с антоциановой окраской и } \\
\text { войлочным опущением средней } \\
\text { густоты. Первые листочки медно- } \\
\text { зеленые, средней густоты войлочного } \\
\text { опушения. } \\
\text { 2. Сформировавшийся лист средний, } \\
\text { округлый, средне-зеленый. } \\
\text { 3. Пластинка листа плоская, края пла- } \\
\text { стинки содержат красный пигмент, } \\
\text { образуя выразительность, } \\
\text { края загнуты вниз, лист 5-лопастной, } \\
\text { среднерассеченный. } \\
\text { 4. Верхняя поверхность } \\
\text { мелкопузырчатая. } \\
\text { 5. Верхние вырезки глубокие, откры } \\
\text { тые или закрытые, форма основания } \\
\text { верхних боковых вырезок \{-образная. } \\
6 . \text { Нижние вырезки средней глубины, } \\
\text { открытые лировидные с узким просве- } \\
\text { том и острым дном или закрытые } \\
\text { с узкоэллиптическим просветом. }\end{array}$ & $\begin{array}{l}\text { 1. Коронка молодого побега зеленая } \\
\text { с паутинистым опушением средней густоты. } \\
\text { Молодые листочки (с } 1 \text { по 3) со светло- } \\
\text { бронзовым оттенком, покрыты густым } \\
\text { или средней густоты паутинистым } \\
\text { опушением. } \\
\text { 2. Лист средний или крупный, 5-7-лопаст- } \\
\text { ной, глубоко рассеченный, с дополнитель- } \\
\text { ными вырезками на основных лопастях. } \\
\text { 3. Пластинка листа почти плоская или ши- } \\
\text { роковоронковидная. } \\
\text { 4. Верхняя поверхность сетчато- } \\
\text { морщинистая. } \\
\text { 5. Верхние вырезки глубокие или очень глу- } \\
\text { бокие, с овальными или яйцевидными про- } \\
\text { светами, закрытые, с округлым дном. } \\
\text { 6. Нижние вырезки глубокие, иногда сред } \\
\text { ней глубины, открытые, лировидные, } \\
\text { с узким устьем или закрытые, с эллиптиче- } \\
\text { скими просветами. } \\
\text { 7. Черешковая выемка открытая лировидная } \\
\text { с заостренным, округлым, изредка плоским }\end{array}$ \\
\hline
\end{tabular}




\begin{tabular}{|c|c|}
\hline $\begin{array}{l}\text { 7. Черешковая выемка открытая, } \\
\text { сводчатая, \{-формы фигурной скобки. } \\
\text { 8. Зубчики на концах лопастей мелкие. } \\
\text { Зубчики по краю листовой пластинки } \\
\text { средние, по обе стороны выпуклые. } \\
\text { 9. Опущение на нижней поверхности } \\
\text { листа густое между главными } \\
\text { жилками. } \\
\text { 10. Черешок темно-розовый, короче } \\
\text { средней жилки. } \\
\text { 11. Осенняя окраска листьев красно- } \\
\text { вато коричневая. } \\
\text { 12. Морозоустойчивость } \\
\text { относительная. } \\
\text { 13.Степень поражения милдью - } 3 \\
\text { балла, оидиумом - } 4 \text { балла, } \\
\text { серой гнилью - 2-3 балла. }\end{array}$ & $\begin{array}{l}\text { дном; у воронковидных листьев она превра- } \\
\text { щается в закрытую с широкоовальным про- } \\
\text { светом. } \\
\text { 8. Зубчики на концах лопастей и по краю } \\
\text { листа треугольные, прямые, острые. } \\
\text { Зубчики по краю листовой пластинки с } \\
\text { сильно выпуклыми сторонами. } \\
\text { 9. Опушение по нижней поверхности листа } \\
\text { густое, паутинистое с примесью щетинок на } \\
\text { жилках. } \\
\text { 10. Черешок листа окрашен в винно- } \\
\text { красный цвет, равен средней жилке. } \\
\text { 11. Осенняя окраска листьев желтая с } \\
\text { винно-красными пятнами. } \\
\text { 12. Морозоустойчивость высокая, } \\
\text { 13. Степень поражения милдью - } \\
\text { 3-4 балла, оидиумом - } 3 \text { балла, } \\
\text { серой гнилью поражается. }\end{array}$ \\
\hline
\end{tabular}

\section{Новый сорт (Гимра х Асыл кара) \\ Фиолетта}

1. Коронка молодого побега светло-зелёная с бронзовым отливом, с войлочным опушением средней густоты. Молодые листочки (с 1 по 3) на выпуклостях паренхимы имеют светло-красные пятна и опушенные с обеих сторон (Асыл кара).

2. Сформировавщийся лист средний или малый (Гимра), клиновидный, среднерассеченный, пять-семь лопастей (Асыл кара)

3. Пластинка листа широковоронковидная (Асыл кара) с загнутыми книзу краями (Гимра).

4. Верхняя поверхность слегка пузырьчатая.

5. Верхние вырезки глубокие, открытые или закрытые, форма основания верхних боковых вырезок \{-образная (Гимра).

6. Нижние вырезки средней глубины, открытые, лировидные (Гимра).

7. Черешковая выемка открытая, треугольная с заостренным дном.

8. Зубчики на концах лопастей треугольные, по краю листа пиловидные, по обе стороны вогнутые и с острыми концами.

9. Опушение по нижней поверхности листа среднее.

10. Черешок темно-розовый, короче средней жилки (Гимра).

11. Осенняя окраска листьев желтовато- красная.

12. Морозоустойчивость относительно высокая.

13. Степень поражения милдью - 3 балла и оидиумом - 4 балла, серой гнилью - 3 балла. 
Плодоводство и виноградарство Юга России № 51(03), 2018 г.

Местные, аборигенные сорта винограда - важная часть генофонда, представляющая интерес для решения прикладных задач селекции и фундаментальных вопросов. Именно в их генотипах могут быть выявлены отдельные или группы признаков, обеспечивающие адаптивность к конкретным агроклиматическим условиям произрастания. В целях изучения разнообразия генетических ресурсов винограда эта группа также представляет большой интерес: аборигенные сорта - источник уникальных аллелей.

Есть предположение, что смещение генотипической структуры в пользу современных сортов привело к снижению или даже исчезновению типичных для региона местных сортов [4].

Генотипирование сортов винограда проводилось следующими маркерными парами: VVS2 + VVMD7; VVMD27 + VVMD5; VrZAG62 + VrZAG79. Получены ДНК-профили аборигенных дагестанских сортов Гимра и Асыл кара и перспективной гибридной формы из их потомства Фиолетта по шести микросателлитным локусам (табл. 2). Каждый сорт винограда имеет свой уникальный ДНК-профиль.

Таблица 2 - ДНК-профили сортов винограда

\begin{tabular}{|c|c|c|c|c|c|c|c|c|c|c|c|c|}
\hline \multirow{2}{*}{ Сорт } & \multicolumn{10}{|c|}{ Аллели SSR-локусов, пары нуклеотидов } \\
\hline & \multicolumn{1}{|c|}{ VVS2 } & \multicolumn{1}{|l|}{ VVMD7 } & \multicolumn{2}{l|}{ VVMD27 } & \multicolumn{2}{l|}{ VVMD5 } & \multicolumn{2}{l|}{ VrZAG62 } & \multicolumn{2}{|l|}{ VrZAG79 } \\
\hline Гимра & 137 & 145 & 244 & 244 & 180 & 182 & 236 & 238 & 196 & 200 & 252 & 260 \\
\hline $\begin{array}{c}\text { Асыл } \\
\text { кара }\end{array}$ & 135 & 145 & 244 & 250 & 182 & 190 & 236 & 242 & 202 & 204 & 238 & 260 \\
\hline Фиолетта & 135 & 145 & 250 & 260 & 182 & 182 & 236 & 242 & 196 & 202 & 260 & 260 \\
\hline $\begin{array}{c}\text { Каберне- } \\
\text { Совиньон }\end{array}$ & 139 & 151 & 240 & 240 & 176 & 190 & 234 & 242 & 188 & 194 & 248 & 248 \\
\hline
\end{tabular}

Анализ профиля ДНК гибридной формы подтвердил её происхождение: каждый проанализированный локус несёт одну отцовскую и одну 
Плодоводство и виноградарство Юга России № 51(03), 2018 г.

материнскую аллель. Неполное соответствие выявлено только по локусу VVMD7: в генотипе гибрида присутствует аллель из одной родительской формы (250 п.н.) - соответствует данным по сорту Асыл Кара, а также аллель размером 260 п.н. Возможно это результат мутации или же требуются уточнения генотипирования по сорту Гимра с использованием ДНК сорта, сохраняемого на коллекции Дагестанской станции.

В целом, микросателлитный анализ генотипов показал сходство по размерам аллелей ряда локусов сортов Гимра и Асыл кара, что свидетельствует об их генетической близости.

Bbыводы. Фенотипическое сходство некоторых признаков аборигенных сортов винограда обусловлено общностью их происхождения, о чем свидетельствуют одинаковые размеры отдельных аллелей изучавшихся одноименных локусов.

Полученные ДНК-паспорта сортов могут эффективно применяться для определения чистосортности посадочного материала и насаждений винограда данных сортов, определения их генетической близости к тому или иному сорту, уточнения родительских форм образца, а также при решении спорных вопросов, касающихся авторства сорта.

\section{Литература}

1. Аджиев, А.М. Эколого-адаптивное виноградарство: научные основы и прикладные аспекты / А.М. Аджиев, Н.А. Аджиева, Х.Г. Азизова, С.А. Аджиева. - Махачкала, 2002. - 279 с.

2. Программа Северо-Кавказского центра по селекции плодовых, ягодных, цветочно-декоративных культур и винограда на период до 2030 года / под общ. ред. Егорова Е.А. - Краснодар, СКЗНИИСиВ, 2013. - 202 с.

3. Петров, В.С. Устойчивость технических сортов винограда разных по экологогеографическому происхождению к основным фитопатогенам. / В.С. Петров, И.А. Ильина, А.И. Талаш, Е.Т. Ильницкая // Виноделие и виноградарство. - 2017. - № 2. C. 21-25.

4. Sabir, A.Genetic Identification and Conservation Local Turkish Grapevine (Vitis vinifera L.) Genotypes on the Edge Extinction, /A. Sabir, H. Ikten, N. Mutlu, D.Sari. // ERWERBS-OBSTBAU. - V. 60. - № 1. - P. 31-38. 
5. Лазаревский М.А. Методы ботанического описания и агробиологического изучения сортов винограда / М.А. Лазаревский // Ампелография СССР. - М.: Пищепромиздат, 1946. - С. 347-401.

6. Лазаревский, М.А. Изучение сортов винограда / М.А. Лазаревский. - Ростов на Дону, 1963. - $151 \mathrm{c}$.

7. Трошин, Л. П. Ампелографический скрининг генофонда винограда: учеб. нагляд. пособие / Л.П. Трошин, Д.Н. Маградзе. - Краснодар: КубГАУ, 2013. - 120 с.

8. Ильницкая, Е.Т. Инструментальные методы оценки исходного и селекционного материала винограда для высококачественного виноделия / Е.Т. Ильницкая, М.А. Сундырева, О.Н. Шелудько, А.В. Прах. - Краснодар, 2015. - 116 с.

9. This P., Jung A., Boccacci P., Borrego J., Botta R., Costantini L., Crespan M., Dangl G. S., Eisenheld C., Ferreira-Monteiro F., Grando S., Ibanez J., Lacombe T., Laucou V., Magalhaes R., Meredith C. P., Milani N., Peterlunger E., Regner F., Zulini L., Maul E. Development of a standard set of microsatellite reference alleles for identification of grape cultivars. Theor. Appl. Genet. 2004; 109: 1448-1458. DOI 10.1007/s00122-004-1760-3

\section{References}

1. Adzhiev, A.M. Jekologo-adaptivnoe vinogradarstvo: nauchnye osnovy i prikladnye aspekty / A.M. Adzhiev, N.A. Adzhieva, H.G. Azizova, S.A. Adzhieva. - Mahachkala, 2002. $-279 \mathrm{~s}$.

2. Programma Severo-Kavkazskogo centra po selekcii plodovyh, jagodnyh, cveochnodekorativnyh kul'tur i vinograda na period do 2030 goda / pod obshhej red. Egorova E.A. Krasnodar, SKZNIISiV, 2013. - 202 s.

3. Petrov, V.S. Ustojchivost' tehnicheskih sortov vinograda raznyh po jekologo-geograficheskomu proishozhdeniju k osnovnym fitopatogenam. / V.S. Petrov, I.A. Il'ina, A.I. Talash, E.T. Il'nickaja // Vinodelie i vinogradarstvo. - 2017. - № 2. - S. 21-25.

4. Sabir, A.Genetic Identification and Conservation Local Turkish Grapevine (Vitis vinifera L.) Genotypes on the Edge Extinction, /A. Sabir, H. Ikten, N. Mutlu, D. Sari. // ERWERBS-OBSTBAU. - V. 60. - №. 1. - P. 31-38.

5. Lazarevskij M.A. Metody botanicheskogo opisanija i agrobiologicheskogo izuchenija sortov vinograda / M.A. Lazarevskij // Ampelografija SSSR. - M.: Pishhepromizdat, 1946. S. 347-401.

6. Lazarevskij, M.A. Izuchenie sortov vinograda / M.A. Lazarevskij. - Rostov na Donu, 1963. - $151 \mathrm{~s}$.

7. Troshin, L. P. Ampelograficheskij skrining genofonda vinograda: ucheb. nagljad. posobie / L.P. Troshin, D.N. Magradze. - Krasnodar: KubGAU, 2013. - 120 s.

8. Il’niczkaya, E.T. Instrumental `nye metody` ocenki isxodnogo i selekcionnogo materiala vinograda dlya vysokokachestvennogo vinodeliya / E.T. Il niczkaya, M.A. Sundyreva, O.N. Shelud ko, A.V. Prax. - Krasnodar, 2015. - 116 s.

9. This P., Jung A., Boccacci P., Borrego J., Botta R., Costantini L., Crespan M., Dangl G. S., Eisenheld C., Ferreira-Monteiro F., Grando S., Ibanez J., Lacombe T., Laucou V., Magalhaes R., Meredith C. P., Milani N., Peterlunger E., Regner F., Zulini L., Maul E. Development of a standard set of microsatellite reference alleles for identification of grape cultivars. Theor. Appl. Genet. 2004; 109: 1448-1458. DOI 10.1007/s00122-004-1760-3 